\title{
PENGARUH MEDIA KARTU BERGAMBAR (FLASH CARD) TERHADAP PENGUASAAN KOSAKATA BAHASA ARAB
}

\author{
Muh. Haris Zubaidillah', Hasan ${ }^{2}$ \\ STIQ Amuntai, Hulu Sungai Utara, Kalimantan Selatan \\ Email: ${ }^{1}$ hariszub@gmail.com, ${ }^{2}$ hasanbanjary@gmail.com
}

\begin{abstract}
Abstrak
Penelitian ini bertujuan untuk: mengetahui pengaruh media kartu bergambar (flash card) terhadap penguasaan kosakata bahasa Arab antara kelas eksperimen dan kelas kontrol. Penelitian ini merupakan penelitian kuasi eksperimen dengan menggunakan tes. Sampel terdiri atas dua unit kelas yaitu kelas eksperimen yang merupakan kelompok siswa yang diberikan perlakuan menggunakan media kartu bergambar (flash card), dan kelas kontrol yaitu kelompok siswa yang tidak diberikan perlakuan menggunakan media kartu bergambar (flash card), kelas kelas eksperimen yaitu IV D dan kelas kontrol yaitu kelas IV B. Data dikumpulkan dengan teknik observasi, tes, dan wawancara. Analisis data dengan menggunakan analisis uji-t satu pihak (independent sample t-test). Hasil penelitian menunjukkan bahwa kurang berpengaruhnya media kartu bergambar (flash card) terhadap penguasaan kosakata bahasa Arab antara kelas eksperimen dan kelas kontrol. Pada hasil uji-t menggunakan independent sample t-test diperoleh nilai signifikansi 0,344, yang artinya pembelajaran dengan menggunakan media kartu bergambar (flash card) kurang berpengaruh dalam meningkatkan penguasaan kosakata bahasa Arab. Walaupun demikian, nilai rata-rata hasil tes penguasaan kosakata bahasa Arab kelas eksperimen lebih besar dari kelas kontrol (77,14 > 72,50) menunjukkan bahwa penguasaan kosakata bahasa Arab kelas eksperimen lebih baik dari kelas kontrol.
\end{abstract}

Kata Kunci: Media Kartu Bergambar, Penguasaan Kosakata, Bahasa Arab.

\section{PENDAHULUAN}

Bahasa Arab merupakan bahasa yang penting bagi masyarakat Islam manapun, karena bahasa Arab merupakan bahasa peribadatan. ${ }^{1}$ Agama Islam mewajibkan kepada pemeluknya agar mempelajari bahasa Arab, karena bahasa Arab adalah bahasa Alquran dan kunci untuk memahaminya, ${ }^{2}$ sebagaimana Allah berfirman dalam Q.S. Y ūsuf/12: 2.3 \section{$1-2$.}

${ }^{1}$ Islam Suardi Wekke, Model Pembelajaran Bahasa Arab (Yogyakarta: Deepublish, 2014), h.

2Mudzakir AS, Studi Ilmu-ilmu Quran (Bogor: Pustaka Litera AntarNusa, 2013), h. 451.

${ }^{3}$ Kementerian Agama R.I., Alqurân dan Terjemahannya (Bandung: PT Sygma Examedia Arkanleema, 2014), h. 235. 


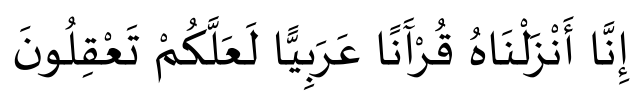

Artinya: Sesungguhnya Kami menurunkannya berupa Alqurân dengan berbahasa Arab, agar kamu memahaminya. (Q.S. Yūsuf/12: 2).

Syaikh Șafiyurrahmān Al-Mubārakfüri dalam kitab Al-Miṣbāh Al-Mun̄r fí Tahzīib Tafsir Ibn Kasīir mengatakan bahwa ayat tersebut menjelaskan tentang bahasa Arab adalah bahasa yang paling fasih, paling jelas, paling luas cakupanya, dan paling tepat untuk dapat menyampaikan makna-makna yang diinginkan hati manusia. Oleh karena itu, kitab yang paling mulia ini diturunkan dengan bahasa yang paling mulia kepada rasul yang paling mulia, melalui malaikat yang paling mulia, ditempat yang mulia di dunia, dan pada bulan yang paling mulia, yaitu Ramadhan. Karenanya, Alqurân adalah kitab yang paling mulia dari segala segi. ${ }^{4}$

Penafsiran ayat di atas dapat disimpulkan bahwa alasan mengapa Allah SWT memilih bahasa Arab sebagai bahasa Alqurân karena bahasa Arab memiliki keistimewaan yaitu sebagai bahasa paling fasih, paling jelas, paling luas cakupannya, dan paling tepat untuk dapat menyampaikan makna-makna Alqurân yang diinginkan hati manusia. Begitu pula Hadis yang merupakan penjelasan dan penafsiran Alqurân, dihimpun dan disusun dalam bahasa Arab. Dalam sebuat hadits yang diriwayatkan dari Ibn 'Abbās, Rasulullah SAW bersabda:
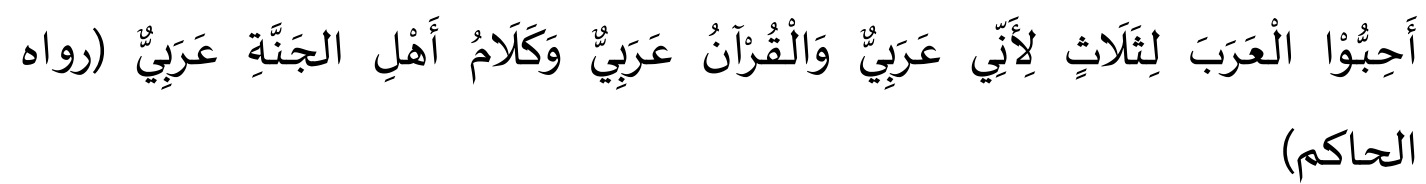

Artinya: "Cintailah bahasa Arab karena tiga hal: aku adalah orang Arab, Alquran berbahasa Arab, dan bahasa ahli surga adalah bahasa Arab." (H.R. AlHâkim).

Sumber pokok agama Islam yaitu Alquran dan Hadis, keduanya berbahasa Arab. ${ }^{5}$

Banyak alasan mengapa orang-orang non Arab mempelajari bahasa Arab, diantaranya:

${ }^{4}$ Syaikh Shafiyurrahman Al-Mubarakfury, Al-Misbâh Al-Munîr fi Tahdzîb Tafsîr Ibn Katsîr, jilid 4 (Bandung: PT. Sygma Examedia Arkanleema, 2012), h. 495-496.

${ }^{5}$ Acep Hermawan, Metodologi Pembelajaran Bahasa Arab, cet. 4 (Bandung: Remaja Rosdakarya Offset, 2014), h. 80. 
1. Motivasi agama terutama Islam karena bahasa kitab suci kaum muslimin barbahasa Arab menjadikan bahasa Arab harus dipelajari sebagai alat untuk memahami ajaran agama yang bersumber dari kitab suci Alqurân,

2. Banyak karya-karya para ulama klasik bahkan hingga yang berkembang dewasa ini menggunakan bahasa Arab dalam kajian-kajian tentang agama dan kehidupan keberagamaan kaum muslimin di dunia. Sehingga, untuk menggali dan memahami hukum maupun ajaran-ajaran agama yang ada di buku-buku klasik maupun modern, mutlak harus mempelajari bahasa Arab. ${ }^{6}$

Pembelajaran bahasa Arab merupakan mata pelajaran yang diarahkan untuk mendorong, membimbing, mengembangkan, dan membina kemampuan serta membutuhkan sikap positif terhadap bahasa Arab, baik reseptif maupun produktif. Kemampuan reseftif yaitu kemampuan untuk memahami bacaan. Kemampuan produktif yaitu kemampuan menggunakan bahasa sebagai alat komunikasi baik secara lisan maupun secara tertulis. Kemampuan berbahasa Arab serta sikap positif terhadap bahasa Arab tersebut sangat penting dalam membantu memahami sumber ajaran Islam yaitu Alqurân dan Al-hadis, serta kitab-kitab berbahasa Arab yang berkenaan dengan Islam bagi peserta didik. Untuk itu bahasa Arab di Madrasah dipersiapkan untuk pencapaian kompetensi dasar berbahasa, yang mencakup empat keterampilan yaitu menyimak, berbicara, membaca, dan menulis. ${ }^{7}$ Penguasaan kosakata akan menjadi penentu seseorang dalam mempelajari bahasa untuk menguasai empat keterampilan berbahasa tersebut.

Menurut David Wilkins sebagaimana dikutip oleh Sesep dan Munawar Mahmud, "Without Grammar very can be conveyed, without vocabulary nothing can be conveyed" tanpa mengetahui grammar (tata bahasa), sedikit sekali yang bisa kita ungkapkan, namun tanpa mengetahui kosakata, tidak ada yang bisa diungkapkan. Dari pernyataan tersebut menandakan bahwa pentingnya kosakata dalam ilmu bahasa. Meski kita mempunyai kemampuan grammar (tata bahasa) yang baik, namun kemampuan tersebut sia-sia saja jika tidak memiliki cukup penguasaan kosakata. ${ }^{8}$ Jadi dapat dikatakan penguasaan kosakata merupakan salah satu syarat bagi seseorang dalam mempelajari bahasa Arab.

\footnotetext{
${ }^{6}$ Acep Hermawan, Metodologi Pembelajaran Bahasa Arab, ..., h. 99.

${ }^{7}$ Asfiati, Pendekatan Humanis dalam Pengembangan Kurikulum, cet. 1 (Medan: Perdana Publishing, 2016), h. 63.

8Sesep dan Munawar Mahmud, Metode Cepat Menghafal $1000++$ Vocabulary \& 16 Tenses, cet. 1 (Jakarta: PT TransMedia, 2012), h. 6.
} 
Kendala yang peneliti jumpai dalam pembelajaran bahasa Arab yaitu materi pembelajaran bahasa Arab masih dianggap sebagai materi pembelajaran yang cukup sulit, menjemukan dan tidak menarik, bahkan ada sebagian siswa merasa takut dengan pelajaran bahasa Arab, sehingga beberapa anak enggan masuk Madrasah, mereka lebih memilih Sekolah Dasar (SD) karena takut dengan mata pelajaran bahasa Arab. ${ }^{9}$ Kendala tersebut terjadi karena siswa tidak memiliki pembendaharaan kosakata yang banyak dan siswa kurang antusias untuk belajar bahasa Arab. Selain itu juga terdapat kendala yang berasal dari guru, diantaranya guru kurang kreatif dan inovatif dalam melaksanakan proses pembelajaran, bahkan guru jarang atau bahkan tidak pernah menggunakan media pengajaran.

Banyak hal yang menjadi alasan tidak digunakannya media dalam proses pembelajaran bahasa Arab, salah satu diantaranya adalah karena menurut guru, penyediaan media pembelajaran membutuhkan biaya yang banyak dan waktu yang cukup panjang. Dalam hal ini guru tidak mau banyak mengambil risiko, sehingga pembelajaran bahasa Arab menjadikan siswa cepat mengalami kebosanan. Padahal kalau seorang guru mau kreatif banyak hal yang bisa dimanfaatkan untuk media pembelajaran bahasa tanpa harus mengeluarkan biaya dan menyita banyak waktu. Guru yang kreatif akan bisa memanfaatkan lingkungan di mana siswa belajar akan dijadikan sebagai objek media pembelajaran. Dengan demikian pembelajaran akan menjadi hal yang sangat mudah dan menyenangkan. ${ }^{1}$

Jadi peneliti berpendapat salah satu solusi dari permasalahan di atas yaitu pemanfaatan media pembelajaran yang dibuat dengan kreatif sesuai dengan materi pembelajaran, agar siswa lebih semangat mengikuti pembelajaran dan lebih efektif dalam menghafal kosakata.

${ }^{9}$ Stigma negatif tentang sulitnya belajar bahasa Arab sebenarnya merupakan propaganda Barat/kolonialis agar umat Islam sedikit demi sedikit menjauhi agamanya, karena bahasa Arab adalah bahasa Al Quran sehingga bila umat Islam jauh dengan Al Quran maka akan jauh pula dengan agamanya. Ketika anggapan tersebut sudah masuk dalam otak bawah sadar siswa, bagaimana pun mudahnya masih saja dikatakan sulit. Kesulitan tersebut biasanya diawali dengan sedikitnya atau bahkan tidak ada sama sekali pemerlehan bahasa siswa disamping permasalahan-permasalahan yang lainnya. Pernyataan seperti di atas dapat kita pastikan dengan menanyakan hal tersebut kepada peserta didik kita semua, mayoritas dari mereka akan menjawab seperti jawaban di atas. Lihat Muhbib Abdul Wahab, Pemikiran Tammam Hassan Dalam Pembelajaran Bahasa Arab, (Jakarta: UIN Jakarta Press, 2009) hal.2. Lihat juga Hasan Hasan, Keterampilan Mengajar Bahasa Arab Materi Istima Menggunakan Media Lagu, Jurnal Ilmiah Al QALAM, Vol. 10, No. 19, Januari-Juni 2017

1 Abdul Wahab Rosyidi, Media Pembelajaran Bahasa Arab, cet. 3 (Malang: UIN-Maliki Press, 2017), h. 20. 
Media pembelajaran adalah semacam alat untuk membantu dalam memperbaiki dan memperjelas, makna kata, kalimat, konsep pemikiran dan bimbingan peserta didik untuk memperoleh keterampilan, kebiasaan, pembelajaran dan fungsi nilai. Media pembelajaran menjadi unsur penting dalam proses pembelajaran bahasa Arab sebagai bahasa asing dilatarbelakangi oleh problematika yang selama ini dirasakan oleh guru bahasa Arab khususnya guru-guru bahasa Arab di madrasah-madrasah. ${ }^{1}$

Salah satu media alternatif yang sangat efektif dan efisien dalam upaya menciptakan pembelajaran yang lebih efektif dalam mengajarkan kosakata baru adalah dengan menggunakan media visual yaitu kartu bergambar (flash card).

Menurut Kasihani, flashcards are teaching aids as picture paper which has $25 \times 30$. The pictures is made by hand, pictures or photo which is stick on the flashcard. ${ }^{1}$ (Flash card adalah ${ }^{2}$ media pembelajaran dalam bentuk kartu bergambar yang berukuran 25x30. Gambar-gambarnya dibuat dengan tangan, foto, atau memanfaatkan gambar / foto yang sudah ada ditempelkan pada lembaran-lembaran flashcard).

Dini Indriana juga mengungkapkan bawa "Flashcard adalah media pembelajaran dalam bentuk kartu bergambar yang ukurannya seukuran postcard atau sekitar 25 X $30 \mathrm{~cm} .{ }^{\prime 1}$

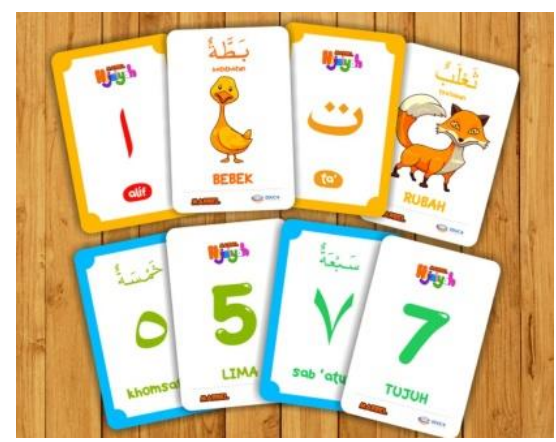

Gambar 1: Contoh Media Flashcard

Dari beberapa pendapat di atas, dapat disimpulkan bahwa flashcard adalah kartu belajar yang efektif mempunyai dua sisi dengan salah satu sisi berisi gambar, teks, atau tanda simbol dan sisi lainnya berupa definisi, keterangan gambar, jawaban, atau uraian yang membantu mengingatkan atau

1 Munir, Perencanaan Sistem Pengajaran Bahasa Arab (Jakarta: Kencana, 2016), h. 125126.

1 Kasihani K.E Suyanto, English for Young Learners Melejitkan Potensi Anak Melalui English Class yang Fun, Asyik, dan Menarik (Jakarta: Bumi Aksara, 2007), h. 109

1 Dina Indriana, Ragam Alat barßtu Media Pengajaran (Yogyakarta: Diva Press, 2011), h. 5 
mengarahkan siswa kepada sesuatu yang berhubungan dengan gambar yang ada pada kartu. Flashcard biasanya berukuran $8 \times 12 \mathrm{~cm}, 25 \times 30 \mathrm{~cm}$, atau dapat disesuaikan dengan besar kecilnya kelas yang dihadapi.

Levie dan Lentz berpendapat bahwa media pembelajaran, khususnya media visual memiliki empat fungsi, yaitu fungsi atensi, fungsi afektif, fungsi kognitif, dan fungsi kompensatoris. Fungsi atensi adalah media visual dapat menarik atau mengarahkan perhatian siswa agar dapat berkonsentrasi pada isi pembelajaran yang terkandung dalam media visual tersebut. Fungsi afektif yaitu media visual dapat digunakan untuk menciptakan rasa senang dan kenikmatan siswa terhadap pembelajaran. Fungsi kognitif adalah media visual dapat mempermudah siswa dalam memahami pesan informasi yang disampaikan dalam pembelajaran. Sedangkan fungsi Kompensatoris adalah media visual dapat mengakomodasi siswa lemah dalam menerima pembelajaran. ${ }^{1}$

Penggunaan media kartu bergambar (flash card) dalam pembelajaran bahasa Arab memiliki nilai positif, diantaranya agar anak lebih mudah mengingat dan menangkap pelajaran, serta pempelajaran akan lebih menyenangkan. ${ }^{1}$ Berdasarkan hasil penelítian yang terdapat dalam Ekopeum, kegiatan belajar mengajar akan lebih efektif dan mudah bila dibantu dengan sarana visual dimana $11 \%$ dipelajari melalui indera pendengaran, sedangkan 83\% lewat indera penglihatan. ${ }^{1}$

6

Beberapa hal yang disebutkan di atas menjadi alasan bagi peneliti untuk mengadakan sebuah penelitian ini. Berdasarkan latar belakang masalah di atas, maka rumusan masalah dalam penelitian ini adalah bagaimana pengaruh media kartu bergambar (flash card) terhadap penguasaan kosakata bahasa Arab di MIN 15 HSU?.

Berdasarkan rumusan masalah yang dikemukakan di atas penelitian ini bertujuan untuk mengetahui Pengaruh Media Kartu Bergambar (Flash Card) Terhadap Penguasaan Kosakata bahasa Arab.

Berikut hipotesis penelitan yang akan digunakan dalam penelitian ini adalah:

$\mathrm{H}_{0}$ : Tidak ada pengaruh media kartu bergambar (flash card) terhadap penguasaan kosakata bahasa Arab.

${ }^{1}$ Abdul Wahab Rosyidi, Media Pémbelajaran Bahasa Arab,..., h. 29.

${ }^{1}$ Rudi Susilana dan Cepi Riyâna, Media Pembelajaran (Bandung: CV Wacana Prima, 2009), h. 95.

1 Sesep dan Munawar Mahmud, Metode Cepat Menghafal $1000++$ Vocabulary \& 16 Tenses,.. . , h. 18 
$\mathrm{H}_{1}$ : Ada pengaruh media kartu bergambar (flash card) terhadap penguasaan kosakata bahasa Arab.

\section{MEDIA KARTU BERGAMBAR (FLASH CARD)}

\section{Pegertian Media Flash Card}

Media kartu bergambar (flash card) adalah media pembelajaran dalam bentuk kartu bergambar. Gambar-gambarnya pada flash card merupakan serangkaian pesan yang disajikan dengan mencatumkan keterangan gambar pada bagian belakang setiap gambar. ${ }^{1}$ Media flash card disebut juga dengan kartu pengingat atau kartu yang diperlihatkan sekilas kepada siswa. Kalimat dan ungkapan yang biasa digunakan dalam flash card adalah topik-topik mengenai alat-alat rumah tangga, binatang, buah-buahan, pakaian, anggota keluarga, dan lain-lain. ${ }^{1}$

\section{Kelebihan Media Flash Card}

Media flash card tergolong dalam media visual (gambar), media flash card memiliki beberapa kelebihan:

a. Mudah dibawa kemana-mana, yakni dengan ukuran yang kecil flash card dapat disimpan di tas bahkan di saku, sehingga tidak membutuhkan ruang yang luas, dapat digunakan di mana saja, di kelas ataupun di luar kelas

b. Praktis, yakni dilihat dari cara pembuatannya dan penggunaannya, media flash card sangat praktis, dalam menggunakan media ini guru tidak perlu memiliki keahlian khusus, media ini tidak perlu juga membutuhkan listrik. Jika akan menggunakannya kita tinggal menyusun urutan gambar sesuai dengan keinginan kita, pastikan posisi gambarnya tepat tidak terbalik, dan jika sudah diguanakan tinggal disimpan kembali dengan cara diikat atau menggunakan kotak khusus supaya tidak tercecer.

c. Gampang diingat, kombinasi antara gambar dan teks cukup memudahkan siswa untuk mengenali konsep sesuatu, untuk mengetahui nama sebuah benda dapat dibantu dengan gambarnya, begitu juga sebaliknya untuk mengetahui nama sebuah benda atau konsep dengan melihat hurufnya atau teksnya.

d. Menyenangkan, media flash card dalam penggunaannya dapat melalui permainan. Misalnya siswa secara berlomba-lomba mencari suatu benda

\footnotetext{
1 Sesep dan Munawar Mahmud, Metode Cepat Menghafal $1000++$ Vocabulary \& 16 Tenses,. . ., h. 18

${ }^{1}$ Acep Hermawan, Metodologi Pe̊mbelajaran Bahasa Arab,..., h. 240.
} 
atau nama-nama tertentu dari flash card yang disimpan secara acak, dengan cara berlari siswa berlomba untuk mencari sesuatu perintah. Selain mengasah kemampuan kognitif juga melatih ketangkasan (fisik). ${ }^{1}$

\section{METODE PENELITIAN}

Penelitian ini menggunakan pendekatan kuantitatif dengan jenis penelitian eksperimen. Desain penelitian yang digunakan dalam penelitian ini adalah desain eksperimen semu (quasi eksperimen design).

Penelitian ini dilaksanakan pada 3 September s.d. 3 Oktober 2018. Pada penelitian ini peneliti menggunakan sekelompok subyek penelitian dari suatu populasi tertentu, maka populasi dalam penelitian ini adalah seluruh siswa kelas IV MIN 15 HSU dan yang menjadi sampel dalam penelitian ini adalah siswa kelas IV D dan IV B yang kemudian dikelompokan menjadi kelompok eksperimen dan kelompok kontrol. Pada kelompok eksperimen diberikan media kartu bergambar (flash card) dan pada kelompok kontrol tidak menggunakan media kartu bergambar (flash card). Media kartu bergambar (flash card) diterapkan di kelas IV D dan kelas IV B tidak menggunakan media kartu bergambar (flash card). Selanjutnya pada kedua kelompok diberikan tes tertulis setelah pemberian perlakuan. Hasil tes tertulis dari kedua kelompok diuji secara statistik dengan menggunakan uji-t independen (Independent Sample t-Test).

Sesuai dengan desain penelitian yang akan digunakan, maka variabelvariabel yang digunakan dalam penelitian ini adalah sebagai berikut:

1. Variabel bebas (independent variable) adalah media kartu bergambar (flash card).

2. Variabel terikat (dependent variable) adalah penguasaan Kosakata bahasa Arab.

Data yang ingin diperoleh dari penelitian ini adalah Penguasaan Kosakata bahasa Arab, maka teknik pengumpulan data yang digunakan dalam penelitian ini yaitu: tes, dokumentasi, observasi.

Berikut ini kisi-kisi instrumen angket motivasi yang di pakai dalam penelitian:

\footnotetext{
1 Rudi Susilana dan Cepi Riyana9, Media Pembelajaran, ... , h. 95.
} 
Muh. Haris Z dan Hasan: Pengaruh Kartu Bergambar (Flash Card) Terhadap Penguasaan Kosakata Bahasa Arab

TABEL KISI-KISI INSTRUMEN TES

\begin{tabular}{|c|c|c|c|c|c|}
\hline $\begin{array}{c}\text { Kompetensi } \\
\text { Inti }\end{array}$ & $\begin{array}{c}\text { Kompetensi } \\
\text { Dasar }\end{array}$ & $\begin{array}{l}\text { Materi } \\
\text { Pokok }\end{array}$ & Indikator & $\begin{array}{l}\text { Bentu } \\
\text { k Soal }\end{array}$ & $\begin{array}{l}\text { No } \\
\text { Soal }\end{array}$ \\
\hline \multirow{4}{*}{$\begin{array}{l}\text { 3. Memaham } \\
\text { i } \\
\text { pengetahu } \\
\text { an faktual } \\
\text { dengan } \\
\text { cara } \\
\text { mengamat } \\
\text { i } \\
\text { (mendeng } \\
\text { ar, } \\
\text { melihat, } \\
\text { membaca) } \\
\text { dan } \\
\text { menanya } \\
\text { berdasark } \\
\text { an rasa } \\
\text { ingin tahu } \\
\text { tentang } \\
\text { dirinya, } \\
\text { makhluk } \\
\text { ciptaan } \\
\text { tuhan dan } \\
\text { kegiatann } \\
\text { ya, dan } \\
\text { benda- } \\
\text { benda } \\
\text { yang } \\
\text { dijumpain } \\
\text { ya di } \\
\text { rumah dan } \\
\text { di sekolah. }\end{array}$} & \multirow{3}{*}{$\begin{array}{l}3.2 \\
\text { Menemukan } \\
\text { makna dari } \\
\text { ujaran } \\
\text { kata, frasa, } \\
\text { dan } \\
\text { kalimat } \\
\text { sederhana } \\
\text { terkait topik : }\end{array}$} & \multirow[t]{3}{*}{ 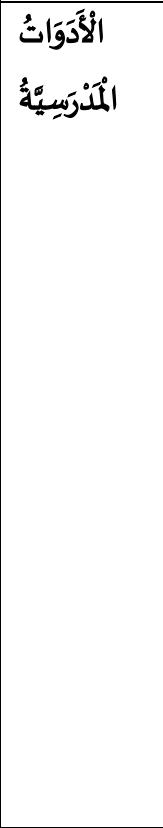 } & 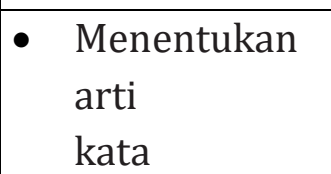 & $\begin{array}{l}\text { Pilihan } \\
\text { ganda }\end{array}$ & 7,8 \\
\hline & & & $\begin{array}{l}\text { - } \text { Menentukan } \\
\text { arti } \\
\text { frase/kalimat }\end{array}$ & & 1,2 \\
\hline & & & 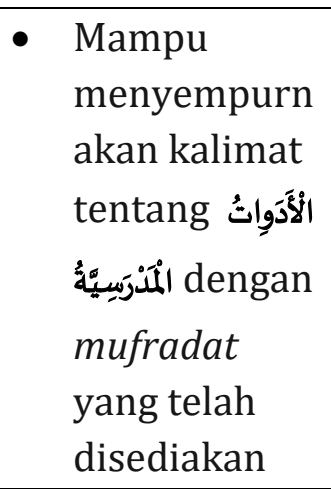 & & 3,4 \\
\hline & 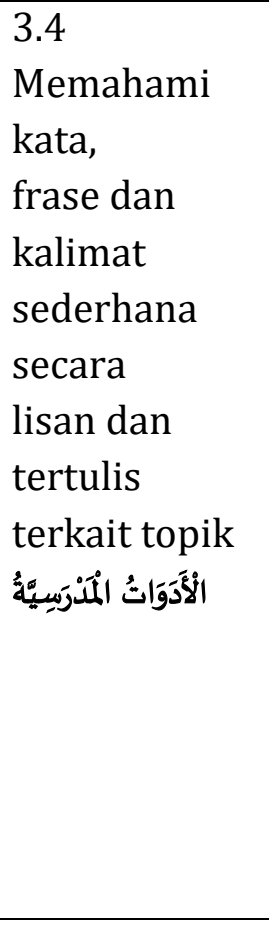 & & 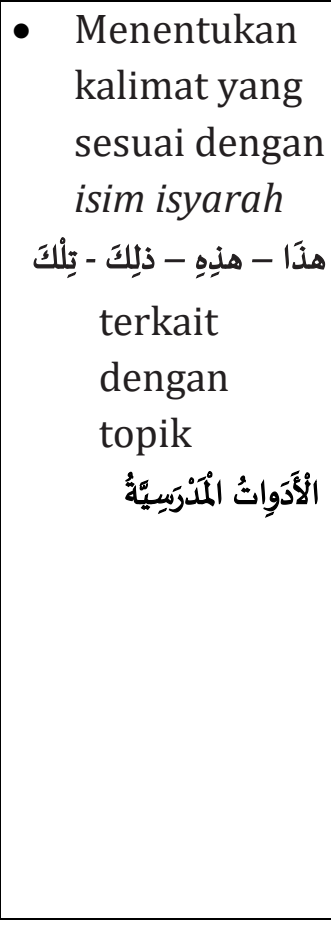 & & $\begin{array}{l}5,6 \\
9,10\end{array}$ \\
\hline
\end{tabular}


Muh. Haris Z dan Hasan: Pengaruh Kartu Bergambar (Flash Card) Terhadap Penguasaan Kosakata Bahasa Arab

Pedoman Penskoran Instrumen Tes

\begin{tabular}{|c|c|c|c|}
\hline Jenis Soal & Bobot Soal & Jumlah Soal & Skor Maksimal \\
\hline Pilihan Ganda & 10 & 10 & 100 \\
\hline \multicolumn{2}{|c|}{ Skor Total Maksimal } & 100 \\
\hline
\end{tabular}

Menentukan kategori tingkat motivasi siswa dapat dilakukan berdasarkan skor perolehan dibagi skor maksimal kemudian dikali 100, seperti rumus dibawah ini:

$$
\text { Nilai akhir }=\frac{\text { skorperolehan }}{\text { skormaksimal }} \times 100
$$

Skor yang diperoleh dari angket motivasi kemudian diinterpretasi menjadi nilai motivasi siswa dengan menggunakan kategori yang diadaptasi dari Zainal Arifin sebagai berikut: ${ }^{2}$

\section{Interpretasi Hasil Angket Motivasi}

\begin{tabular}{|c|c|}
\hline Nilai & Kualifikasi Motivasi \\
\hline $85-100$ & Sangat Tinggi \\
\hline $70-84$ & Tinggi \\
\hline $55-69$ & Cukup \\
\hline $40-54$ & Rendah \\
\hline $25-39$ & Sangat Rendah \\
\hline
\end{tabular}

Analisis data akan menampilkan data penguasaan kosakata bahasa Arab kelas eksperimen dan penguasaan kosakata bahasa Arab kelas kontrol, kemudian dilakukan pengujian hipotesis, dengan menggunakan diuji statistik Independent Sample t-Test memakai bantuan software SPSS version 22 for windows dengan taraf signifikan yang diterapkan yaitu kesalahan $5 \%$.

Penggunaan Independent Sample t-Test harus memenuhi persyaratan distribusi normal maka dilakukan uji normalitas (uji Shapiro-Wilk) dan variansi antar kelompok homogen maka dilakukan uji homogenitas (uji $\mathrm{F}$ (Levene's Test for Equality of Variances) dengan taraf signifikan yang diterapkan yaitu kesalahan $5 \%$.

2 Zainal Arifin, Evaluasi Pelmbelajaran, Prinsip-Teknik-Prosedur (Bandung: PT Remaja Rosdakarya, 2012), h. 45. 


\section{HASIL PENELITIAN DAN PEMBAHASAN}

Penelitian ini menggunakan desain eksperimen dengan menggunakan media kartu bergambar (flash card) untuk mengetahui peningkatan penguasaan kosakata bahasa Arab di kelas IV D dan penguasaan kosakata bahasa Arab di kelas IV B. Subyek penelitian ini terdiri dari dua kelas yaitu kelas ekperimen di kelas IV D diberi perlakuan dengan menggunakan media kartu bergambar (flash card) dan kelas kontrol di kelas IV B dilakukan proses pembelajaran seperti biasa yaitu tidak menggunakan media. Kelas eksperimen berjumlah 21 siswa dan kelas kontrol berjumlah 20 siswa.

Sebelum menganalisis data menggunakan independent sample t-test, data harus memenuhi syarat. Data yang akan di uji harus berdistribusi normal dan berasal dari varian yang sama, oleh karena itu dilakukan terlebih dahulu uji normalitas dan uji homogenitas.

Uji Shapiro-Wilk digunakan untuk mengetahui normalitas data tes penguasaan kosakata bahasa Arab di kelas IV D dan IV B. Dasar Pengambilan Keputusan dalam Uji Normalitas Shapiro-Wilk adalah sebagai berikut:

1. Jika nilai sig. $>0,05$, maka data berdistribusi normal

2. Jika nilai sig. $<0,05$, maka data tidak berdistribusi normal

Adapun data hasil uji normalitas data tes penguasaan kosakata bahasa Arab di kelas IV D dan IV B adalah sebagai berikut:

\section{Uji Normalitas Data Tes Penguasaan Kosakata bahasa Arab} Kelas Eksperimen dan Kelas Kontrol

\begin{tabular}{|ll|r|r|r|}
\hline Kelas & \multicolumn{3}{|c|}{ Shapiro-Wilk } \\
\cline { 3 - 5 } & & Statistic & \multicolumn{1}{|c|}{ Df } & \multicolumn{1}{c|}{ Sig. } \\
\hline \multirow{2}{*}{ Nilai } & Kelas Ekspremen &, 905 & 21 &, 052 \\
& Kelas Kontrol &, 882 & 20 &, 016 \\
\hline
\end{tabular}

Berdasarkan tabel di atas menunjukkan bahwa hasil uji normalitas dengan menggunakan uji Shapiro-Wilk pada tabel di atas menunjukkan bahwa nilai signifikansi data Motivasi Belajar Membaca Alquran kelas eksperimen adalah 0,052 dan data tes penguasaan kosakata bahasa Arab kelas kontrol adalah 0,016. Kedua nilai signifikansi tersebut lebih besar dari 0,05, maka dapat disimpulkan bahwa data tes penguasaan kosakata bahasa Arab kelas eksperimen dan kelas kontrol berdistribusi normal dan sudah memenuhi 
prasyarat untuk melakukan uji selanjutnya. Adapun rincian lengkap output uji normalitas menggunakan SPSS Version 22 for Windows terdapat di lampiran.

Uji prasyarat yang kedua untuk melakukan analisis independent sampel $T$ Tes adalah uji homogenitas yang bertujuan untuk mengetahui apakah data berasal dari varian yang sama atau tidak. Uji homogenitas menggunakan uji Levene dengan bantuan program SPSS Version 22 for Windows dengan dasar Pengambilan Keputusan dalam Uji homogenitas sebagai berikut:

- Nilai signifikansi (p) > 0.05 menunjukkan kelompok data berasal dari populasi yang memiliki varians yang sama (homogen)

- Nilai signifikansi (p) $<0.05$ menunjukkan masing-masing kelompok data berasal dari populasi dengan varians yang berbeda (tidak homogen)

Adapun data hasil tes penguasaan kosakata bahasa Arab di kelas IV D dan IV B adalah sebagai berikut:

\section{Uji Homogenitas Data Tes Penguasaan Kosakata bahasa Arab Kelas Eksperimen dan Kelas Kontrol Nilai}

\begin{tabular}{|r|r|r|c|}
\hline Levene Statistic & \multicolumn{1}{c|}{ df1 } & df2 & \multicolumn{1}{c|}{ Sig. } \\
\hline, 286 & 1 & 39 &, 596 \\
\hline
\end{tabular}

Berdasarkan tabel di atas menunjukkan bahwa uji homogenitas dengan menggunakan uji Levene Statistic nilai signifikansi data tes penguasaan kosakata bahasa Arab kelas kontrol dan kelas eksperimen adalah 0,596. Nilai ini lebih besar dari 0,05, maka data tersebut homogen. Adapun rincian output yang lengkap uji homogenitas data di atas terdapat pada lampiran.

Pengujian hipotesis merupakan langkah untuk menentukan apakah hipotesis diterima atau ditolak. Data yang digunakan adalah data tes penguasaan kosakata bahasa Arab eksperimen dan kontrol. Hipotesis yang akan diujikan pada bagian ini adalah:

$\mathrm{H}_{0} \quad$ : Tidak ada pengaruh media kartu bergambar (flash card) terhadap penguasaan kosakata bahasa Arab.

$\mathrm{H}_{1}$ : Ada pengaruh media kartu bergambar (flash card) terhadap penguasaan kosakata bahasa Arab. 
Dasar pengambilan keputusan hipotesis di atas dilihat dari nilai signifikansi sebagai berikut:

- Apabila nilai probabilitas (p) $>0,05$ maka $\mathrm{H}_{0}$ diterima.

- Apabila nilai probabilitas (p) <0,05 maka Ho ditolak.

Pengujian hepotesis tersebut dilakukan dengan independent sample $t$ test, dengan menguji perbedaan data tes penguasaan kosakata bahasa Arab kelas kontrol dan kelas eksperimen. Berikut rangkuman hasil analisis independent sample t-test dengan menggunakan bantuan SPSS version 22 for windows untuk mengukur perbedaan data tes penguasaan kosakata bahasa Arab kelas kontrol dan kelas eksperimen setelah diberikan perlakuan:

Rangkuman Hasil Analisis Independent Sample T-Test Antar Kelompok Data Tes Penguasaan Kosakata bahasa Arab

\begin{tabular}{|r|r|c|c|c|}
\hline \multicolumn{2}{|c|}{ Mean \pm Standar Deviasi } & \multirow{2}{*}{ thitung } & P & \multirow{2}{*}{ Keterangan } \\
\hline Eksperimen & Kontrol & & & \\
\hline $77,14 \pm$ & $72,50 \pm$ & \multirow{2}{*}{0,957} & 0,344 & Tidak Signifikan \\
16,50 & 14,54 & & & \\
\hline
\end{tabular}

Hasil analisis menunjukkan bahwa nilai t-hitung sebesar 0,344 dengan nilai signifikansi $p$-value sebesar 0,344 . Hal ini menunjukkan bahwa niali thitung lebih kecil dari t-tabel dan nilai signifikansi $p$-value lebih besar dari taraf signifikansi yang artinya bahwa Ho diterima, maka dapat disimpulkan bahwa tidak ada pengaruh media kartu bergambar terhadap penguasaan kosakata bahasa Arab antara kelas kontrol dan kelas eksperimen. Namun nilai rata-rata hasil tes penguasaan kosakata bahasa Arab kelas eksperimen lebih besar dari kelas kontrol $(77,14>72,50)$ menunjukkan bahwa penguasaan kosakata bahasa Arab kelas eksperimen lebih baik dari kelas kontrol.

\section{SIMPULAN}

Berdasarkan hasil analisis data dan pembahasan yang telah dilakukan, maka diperoleh kesimpulan bahwa media kartu bergambar kurang berpengaruh dalam meningkatkan penguasaan kosakata bahasa Arab. Pada hasil uji-t menggunakan independent sample t-test dengan membedakan data hasil tes penguasaan kosakata bahasa Arab diperoleh nilai signifikansi 0,344, nilai tersebut lebih dari 0,05 maka $\mathrm{H}_{0}$ diterima dan $\mathrm{H}_{1}$ ditolak, artinya tidak ada pengaruh media kartu bergambar terhadap penguasaan kosakata bahasa 
Arab antara kelas kontrol dan kelas eksperimen. Namun nilai rata-rata hasil tes penguasaan kosakata bahasa Arab kelas eksperimen lebih besar dari kelas kontrol $(77,14>72,50)$ menunjukkan bahwa penguasaan kosakata bahasa Arab kelas eksperimen lebih baik dari kelas kontrol.

Untuk dapat meningkatkan penguasaan siswa terhadap kosa kata bahasa Arab perlu menggunakan media yang cocok dan kreatif. Media flashcard adalah salah satu media kreatif yang dapat digunakan untuk meningkatkan daya tangkap siswa dalam menguasai kosa kata khususnya pada pelajaran bahasa Arab. Respon atau minat siswa terhadap bidang studi bahasa Arab bisa dirangsang dengan beberapa metode dan media pembelajaran yang menarik dan efisien, salah satunya bisa dengan menggunakan media flashcard.

Dalam penggunaan media flashcard disarankan kepada para guru agar selalu mempersiapkan pembelajaran bahasa Arab yang kreatif, supaya siswa tidak merasa monoton dalam belajar bahasa Arab. Akan tetapi merasa bersemangat dan senang terhadap metode atau cara yang disampaikan. Begitu juga para staf pendidik khususnya pengajar di lembaga pendidikan terkait dapat meyakinkan para siswa didiknya khususnya dalam belajar bahasa Arab bukanlah pembelajaran yang sangat melelahkan dan membosankan.

\section{DAFTAR PUSTAKA}

Al-Mubarakfury, Syaikh Shafiyurrahman. Al-Misbâh Al-Munir fi Tâhdzib Tâfsir Ibnu Kâtsir. Bandung: PT. Sygma Examedia Arkanleema, 2012.

Arifin, Zainal. Evaluasi Pembelajaran, Prinsip-Teknik-Prosedur. Bandung: PT Remaja Rosdakarya, 2012.

Asfiati. Pendekatan Humanis dalam Pengembangan Kurikulum. Medan: Perdana Publishing, 2016.

Hasan, Hasan, Media Musik dan Lagu dalam Pembelajaran Bahasa Arab. Banjarmasin: Dreamedia, 2016.

Hermawan, Acep. Metodologi Pembelajaran Bahasa Arab. Bandung: Remaja Rosdakarya Offset, 2014. 
Muh. Haris Z dan Hasan: Pengaruh Kartu Bergambar (Flash Card) Terhadap Penguasaan Kosakata Bahasa Arab

Kementerian Agama R.I.. Alqurân dan Terjemahannya. Bandung: PT Sygma Examedia Arkanleema, 2014.

Mudzakir. Studi Ilmu-ilmu Qûrân Terjemahan Mâbâhis fi Ulumil Qurân oleh Mânnấ' khâlil al-Qattân.. Bogor: Pustaka Litera AntarNusa, 2013.

Munir. Perencanaan Sistem Pengajaran Bahasa Arab. Jakarta: Kencana, 2016.

Rosyidi, Abdul Wahab. Media Pembelajaran Bahasa Arab, Malang: UIN-Maliki Press, 2017.

Sesep dan Munawar Mahmud. Metode Cepat Menghafal 1000 ++ Vocabulary \& 16 Tenses. Jakarta: PT TransMedia, 2012.

Susilana, Rudi dan Cepi Riyana. Media Pembelajaran. Bandung: CV Wacana Prima, 2009.

Wekke, Islam Suardi. Model Pembelajaran Bahasa Arab. Yogyakarta: Deepublish, 2014. 
Muh. Haris Z dan Hasan: Pengaruh Kartu Bergambar (Flash Card) Terhadap Penguasaan Kosakata Bahasa Arab 